Advance Journal of Food Science and Technology 14(6): 186-193, 2018

DOI:10.19026/ajfst.14.5980

ISSN: 2042-4868; e-ISSN: 2042-4876

(C) 2018 Maxwell Scientific Publication Corp.

Submitted: June 11, $2018 \quad$ Accepted: September 7, 2018

Published: October 25, 2018

\title{
Research Article \\ Effect of Egg White Hydrolysates on the Shrinkage, Cooking Loss and Texture of Pork Meat Slices
}

\author{
${ }^{1,3}$ Yu Wang, ${ }^{2}$ Hirofumi Enomoto, ${ }^{3}$ Jufang Shen and ${ }^{1}$ Hajime Hatta \\ ${ }^{1}$ Department of Food and Nutrition, Kyoto Women's University, Kyoto, 605-8501 \\ ${ }^{2}$ Department of Biosciences, Teikyo University, Tochigi, 320-8551, \\ ${ }^{3}$ Department of Research, China Jilin Jinyi Egg Products CO., LTD., Dongliao Modern Agricultural and \\ Technology Industrial Park, Jilin 136200, China.
}

\begin{abstract}
The potential of using hydrolyzed egg white (hEW) as a food additive to decrease shrinkage, cooking loss of pork meat slices was investigated. Functional characteristics including solubility, Water-Holding Capacity (WHC) and Oil-Binding Capacity (OBC) of three hEWs by using different kinds of enzymes, a commercial small size peptide $\mathrm{S}$ and native egg white (NEw) were evaluated. Pork meat slices $(8 \mathrm{~cm} \times 6 \mathrm{~cm})$ with thickness of $4 \mathrm{~mm}$ were soaked in the same weight of solution contained $\mathrm{hEW}$, small peptide $\mathrm{S}$ or NEw at a protein concentration of $10 \%(\mathrm{w} / \mathrm{v})$ at $4^{\circ} \mathrm{C}$ for $24 \mathrm{~h}$ respectively. Results showed that, cooking loss (\%) and shrinkage rate (\%) decreased when raw meat was immersed in the solution which contained hEWs or NEw. Meat treated by hEW obtained by using enzyme-Thermoase $\mathrm{PC} 10 \mathrm{~F}^{\circledR}$ showed an excellent $\mathrm{WHC}$ and resulted in the least shrinkage rate (3.2\%) compared with the meat soaked in the same portion of water (shrinkage rate of $22.7 \%$ ). Moreover, by using a scanning electron microscopy, relative larger holes and a grainy appearance of endomysium sheaths were also observed in the meat treated by this hEW. Treated by hEWs and NEw contributed to the decrease of elasticity and toughness of cooked meat. Thus, treated by hEWs may permit reduction in cooking loss as and shrinkage rate of pork meat slices.
\end{abstract}

Keywords: Cooking loss, egg white hydrolysate, microstructure, pork meat slices, shrinkage rate

\section{INTRODUCTION}

Cooking of meat is essential for sterilizing foodborne pathogens, assuring microbial safety and achieving meat quality (Pathare and Roskilly, 2016). During cooking, the distinctive meat proteins are heat denatured and result in destruction of cell membranes, shrinkage of meat fibers, the aggregation and gel formation of myofibrillar and sarcoplasmic proteins, as well as the shrinkage and solubilization of the connective tissue (Pathare and Roskilly, 2016; Tornberg, 2005). Meat shrinkage and cooking loss during cooking has been often thought to be the poor meat quality indication by consumers (Barbera and Tassone, 2006). And from a nutritional perspective, cooking loss also brings loss of soluble proteins, vitamins and other micronutrients (Yarmand et al., 2013).

In order to avoid or decrease shrinkage and cooking loss of meat, lots of studies have been performed. Heating temperature was proved to affect the texture of meat. A low cooking temperature yielded a tender product with lower cooking losses (Marshall et al., 1960; Penfield and Meyer, 1975). Moreover, cooking method was also shown to have effect on the physical properties and cooking loss of meat. Dominguez et al. (2014) proved that microwave cooking resulted in the highest cooking loss of foal meat comparing with other cooking methods (roasting, grilling and frying).

Except for cooking method, different ways of meat treatment have also been studied to enhance the appearance and flavor of meat products. Polyphosphates are known to change $\mathrm{pH}$ value, increase the amount of water bound, decrease losses of weight in cooking, improve texture and sensory properties (tenderness, juiciness, color and flavor) and extend shelf-life, etc., they have been widely used in meat processing industry (Long et al., 2006). However, an avoidable risk to human health arises from the increased use of phosphates as food additives and preservatives, as cardiovascular morbidity and mortality are found to be associated with high intake of phosphate additives (Glorieux et al., 2017; Ritz et al.,

Corresponding Author: Hajime Hatta, Department of Food and Nutrition, Kyoto Women's University, 605-8501, Kyoto, Japan, Tel.: 81-75-531-7143

This work is licensed under a Creative Commons Attribution 4.0 International License (URL: http://creativecommons.org/licenses/by/4.0/). 
2012). The role of proteins is also very important for sensory properties and quality of meat products. Lean meat content (protein content) should be sufficient enough to stabilize the emulsion and the gel formation during heating (Omana et al., 2012). Cereal and legume proteins can be added to meat products to help reduce formulation costs and cook loss, to improve nutritional value and to aid in emulsifying capacity and emulsion stability (Mittal and Usborne, 1985). Proteins from soybean are also commonly used in processed meat products due to their low cost and functional properties (Omana et al., 2012). Soy Protein Isolate (SPI) as a binder are widely used in processed meat, resulting in reduced costs and water loss (Homco-Ryan et al., 2003). The U.S. Department of Agriculture allows cereal-based materials to be incorporated at levels up to $3.5 \%$ of the meat formulations, SPI is limited to $2 \%$ (Homco-Ryan et al., 2003).

Egg white is also used in cooked sausages such as frankfurter because of its ability to form a stable and heat-irreversible gel, thus positively contributing to the firmness of low-cost emulsified sausages. The addition rate of egg white varies widely, high inclusion levels result in an egg flavor within the finished product (Keeton, 2001). However, study on the utilization of proteins in non-ground meat is still restricted.

In our previous study, the emulsifying activity and emulsifying stability of egg white were improved by partially hydrolysis using a protease-Thermoase PC10F ${ }^{\circledR}$, the improved emulsifying properties were comparative to that of egg yolk. Therefore, the $1^{\text {st }}$ objective of this study was to evaluate functional characteristics of hydrolyzed Egg White (hEW) including solubility, Water-Holding Capacity (WHC) and Oil-Binding Capacity (OBC) in relation to enzyme types used in the hydrolysis process; The $2^{\text {nd }}$ objective was to compare the cook loss and shrinkage rate of pork meat slices soaked in different $\mathrm{hEW}$ solutions.

\section{MATERIALS AND METHODS}

Preparation of egg white hydrolysates: Hen eggs were obtained from a local supermarket (Kyoto, Japan) and were manually broken and separated yolk from egg white. Egg white was mixed using a hand mixer (National MK-210, Japan) at a rotational speed of 540 rpm for $3 \mathrm{~s}$, then filtered by passing through stainless mesh (sieve size $0.60 \mathrm{~mm}$ ), any foam was removed. The $\mathrm{pH}$ of egg white was adjusted to each optimal working $\mathrm{pH}$ as shown in Table 1 with $10 \%(\mathrm{w} / \mathrm{v})$ citric acid solution before using for the experiment.

Enzyme was added at a concentration of $0.4 \%$ (w/w) after being warmed up to $50^{\circ} \mathrm{C}$. Three kinds of enzymes: Protin NY100 ${ }^{\circledR}$, Thermoase PC10F $^{\circledR}$, Protease $\mathrm{M}^{\circledR}$, provided by Amano Enzyme Inc. (Japan) have been used in this study, the hEWs obtained using these three enzymes were named: PNY, T and PM, respectively.
Enzymatic treatment was conducted as follows: 10 min at $50^{\circ} \mathrm{C}$, then adjusted to its corresponding optimal working temperature and maintained for $30 \mathrm{~min}$ before inactivation. Inactivation of enzyme was achieved by holding the resulting hydrolysates at $90^{\circ} \mathrm{C}$ for $8 \mathrm{~min}$, before homogenization by a mechanical homogenizer (IKA T18 basic, Germany) at Dial 5 (15,000 rpm) for 60s. To ensure enzyme was completely inactivated, $x-$ ray films (Fuji Film, Japan) were used. The surface of $\mathrm{x}$-ray film is covered with thin gelatin film, which is hydrolyzed by the possible remained active enzyme, leading to the appearance of transparency of the films. Samples of hEWs were then freeze-dried (FreeZone Plus 12 L Cascade Console Freeze Dry System, Labconco, Japan) and stored as powder at $-30^{\circ} \mathrm{C}$.

Peptide $\mathrm{S}$ is a mixture of egg white peptides (Runpep $^{\circledR}$ ) with molecular weight lower than $10 \mathrm{kDa}$ (as reported in the product description) provided by Pharma Foods International Co. Ltd, Japan. Peptide S (protein concentration of $80 \%$ ) was dissolved in distilled water at a concentration of $100 \mathrm{mg}$ (protein) $/ \mathrm{ml}$ as a reference sample, which was then stored at $4^{\circ} \mathrm{C}$ until use.

Surface hydrophobicity: Samples were diluted with phosphate buffer (0.01 M, pH 7.0) before centrifuging at 10,000 rpm for $10 \mathrm{~min}$ (CFRX II, Hitachi, Japan) and supernatant of each sample was stored at $4^{\circ} \mathrm{C}$ for further analysis. Protein surface hydrophobicity $\left(\mathrm{H}_{0}\right)$ was measured using fluorescence probe 1anilinonaphthalene-8 sulfonic acid (ANS, Sigma Chemical Co.) as described by Kato and Nakai (1980). ANS solution ( $45 \mu \mathrm{L}, 8 \mathrm{mM}$ ) was added to $3 \mathrm{~mL}$ sample solution $(0.1 \mathrm{mg} / \mathrm{mL})$. ANS fluorescence intensity was scanned from $420 \mathrm{~nm}$ to $570 \mathrm{~nm}$ with excitation at $390 \mathrm{~nm}$. Excitation and emission slits were $2.5 \mathrm{~nm}$. The curve of fluorescence intensity versus wavelength of sample was analyzed.

Particle size measurement: hEW (PNY, T and PM) or native egg white (NEw) was diluted to the final protein concentration of $2 \%(\mathrm{w} / \mathrm{v})$ with denionized water. Then the protein solutions were mixed with colza oil at a volume ratio of 9:1, followed by pre-homogenizing for 2 min at 13,000 rpm using a homogenizer (Polytron PTMR2100, Switzeland) equipped with a $5 \mathrm{~mm}$ diameter head. The resulting emulsions were sealed and stored at $4^{\circ} \mathrm{C}$ until analysis. Droplet size distribution profiles of various freshly prepared emulsions were obtained with a laser diffraction particle size analyzer (SALD-2200, Shimadzu, Japan). Droplet size measurements were reported as the volume-average droplet size, $\mathrm{d}_{3,2}=$ $\left(\sum \mathrm{n}_{\mathrm{i}} \mathrm{d}_{\mathrm{i}}^{3} / \mathrm{n}_{\mathrm{i}} \mathrm{d}_{\mathrm{i}}^{2}\right)$, where $\mathrm{n}_{\mathrm{i}}$ is the number of droplets with diameter $\mathrm{d}_{\mathrm{i}}$ (Chang et al., 2016). All determinations were conducted on individual sample in triplicates. 
Adv. J. Food Sci. Technol., 14(6): 186-193, 2018

Table 1: Working condition of enzymes

\begin{tabular}{llll}
\hline Enzyme name & Proteolytic activity of enzyme & Optimal Temperature and $\mathrm{pH}$ & Enzyme Inactivation temperature $/ \mathrm{T}^{\circ} \mathrm{C}$ \\
\hline Protin $\mathrm{NY} 100 \AA$ & $900,000 \mathrm{U} / \mathrm{g}$ & $50^{\circ} \mathrm{C} ; \mathrm{pH} \mathrm{7.0}$ & $65-70^{\circ} \mathrm{C}$ \\
ThermoasePC10F® & $700,000 \mathrm{U} / \mathrm{g}$ & $65^{\circ} \mathrm{C} ; \mathrm{pH} \mathrm{7.5}$ & $85-90^{\circ} \mathrm{C}$ \\
Protease $\mathrm{M}{ }^{\circledR}$ & $40,000 \mathrm{U} / \mathrm{g}$ & $50^{\circ} \mathrm{C} ; \mathrm{pH} 6.0$ & $60-70^{\circ} \mathrm{C}$ \\
\hline
\end{tabular}

Solubility: Solubility was determined using method described by Snyder and Kwon (1987) with slight modifications. An aqueous solution $(1.0 \%, \mathrm{w} / \mathrm{v})$ of samples in deionized water was stirred magnetically for $30 \mathrm{~min}$. Then it was centrifuged at 13,500 rpm for 30 $\min$ at $4^{\circ} \mathrm{C}$ (CFRX II, Hitachi, Japan). After an appropriate dilution with deionized water, protein content of the supernatant was determined by the method of Markwell et al. (1978). The soluble protein percentage was expressed as (protein content of the supernatant $) /($ sample protein content $) \times 100$.

Water-holding capacity: Water-Holding Capacity (WHC) was determined as described by D'Appolonia (1977). Samples (1 g) added to centrifuge tubes (15 $\mathrm{mL})$ containing distilled water $(9 \mathrm{~mL})$. Tubes were shaken at room temperature for $2 \mathrm{~h}$. Samples were then centrifuged at 9,000 rpm (CFRX II , Hitachi, Japan) for $30 \mathrm{~min}$ at $20^{\circ} \mathrm{C}$. Then tubes were inverted and allowed to drain for $10 \mathrm{~min}$, supernatant was decanted, drained weight was determined. WHC was determined as percent of water retention.

Oil-binding capacity: Oil-Binding Capacity (OBC) was determined using a modified method of HomcoRyan et al. (2003) and Seguchi (2010). Sample (0.3 g) was combined with colza oil $(3 \mathrm{~mL})$ in a $15-\mathrm{mL}$ plastic test tube. Tubes were shaken vigorously by a mechanical shaker for $1 \mathrm{~min}$ before standing at room temperature for $1 \mathrm{~h}$. Then samples were centrifuged at $3,500 \times \mathrm{g}$ for $25 \mathrm{~min}$ at $20^{\circ} \mathrm{C}$. Tubes were inverted and allowed to drain for $30 \mathrm{~min}$, drained weight was determined. OBC was calculated as:

$$
\text { OBC }(\%)=\text { oil bound }(\mathrm{g}) / \text { sample }(\mathrm{g}) \times 100
$$

Treatment of pork slices with egg white hydrolysates. Approximately $8 \mathrm{~cm} \times 6 \mathrm{~cm}$ of lean pork (leg meat) slices with thickness of $4 \mathrm{~mm}$ were supplied by a local butcher shop (Kyoto, Japan). Visible fats and connective tissues were trimmed. Fresh meat $\mathrm{pH}$ was determined as described by Pigott et al. (2010) (data were not shown). Each piece of pork slice was weighed $\left(\mathrm{W}_{0}\right)$, shape of each slice was copied using a printer (DCP-9020CDW, Brother, Japan), paper was cut carefully by following the outline of each copied meat, the cut paper was weight $\left(\mathrm{W}_{0}{ }^{*}\right)$. Then meat was soaked individually in the same weight of hEW solution (protein concentration of $10 \%, \mathrm{w} / \mathrm{v}$ ) in a zipper freezer bag, then it was stored in fridge at $4^{\circ} \mathrm{C}$ for $24 \mathrm{~h}$ until further analysis (Pigott et al., 2010).
Absorption rate, shrinkage and water loss rate of pork slices soaked in different egg white hydrolysate solutions. Treated meat slices were slightly rinsed by distilled water and then placed on a kitchen paper for 1 min to avoid extra moisture. Pork slice was weighed individually $\left(\mathrm{W}_{1}\right)$, shape of each slice was copied and cut as mentioned before, the cut paper of meat after soaking in $\mathrm{hEW}$ was weighed $\left(\mathrm{W}_{1}{ }^{*}\right)$. Meat was cooked using a hotplate (EA-XC45-HW, Zojirushi, Japan). The highest temperature of hotplate (about $250^{\circ} \mathrm{C}$ ) was applied. Each side of meat was roasted at the same place of hotplate for $30 \mathrm{~s}$. Cooked meat slice was weighed $\left(\mathrm{W}_{2}\right)$, shape of each cooked meat slice was copied and cut as mentioned before, the cut paper of cooked meat was weighed $\left(\mathrm{W}_{2}{ }^{*}\right)$. Absorption rate, shrinkage and water loss rate were calculated follows:

Absorption rate $(\%)=\left(\mathrm{W}_{1}-\mathrm{W}_{0}\right) / \mathrm{W}_{0} \times 100$

Cooking loss $(\%)=\left(\mathrm{W}_{0}-\mathrm{W}_{2}\right) / \mathrm{W}_{0} \times 100$

Shrinkage $(\%)=\left(\mathrm{W}_{0}{ }^{*}-\mathrm{W}_{2}{ }^{*}\right) / \mathrm{W}_{0}{ }^{*} \times 100$

Water content of cooked pork slices treated by hydrolyzed egg white: Cooked meat slice was cut down to about $1 \times 1 \mathrm{~cm}$, then meat was dried using at $120^{\circ} \mathrm{C}$ for $24 \mathrm{~h}$ using a drying oven (DS600, Yamato Scientific, Japan). Water content of cooked meat was calculated as:

Water content $=($ Initial weight-final drying weight $)$ $/$ Initial weight $\times 100$

Texture evaluation: Tests were performed with a Texo-Graph (Japan Food R\&D Institute, Japan). A compression test with a cylindrical plunger of $0.5 \mathrm{~cm}^{2}$ was performed to determine textural characteristics of meat slices after cook. The probe extruded on the surface of cooked meat at a rate of $0.8 \mathrm{~mm} / \mathrm{s}$ and the force exerted on the probe was automatically recorded as a load deformation curve which corresponded to textural characteristics of hardness (and toughness) and elasticity. Measurements were developed four times for each sample.

Micro structure: Cooked meat was cut down to about $1 \times 1 \mathrm{~cm}$, then freeze-dried (FreeZone Plus $12 \mathrm{~L}$ Cascade Console Freeze Dry System, Labconco, Japan) for overnight. Thin silk of the dried specimens was mounted on metal stubs with double-stick tape, coated with gold (JEC- 3000 FC Auto Fine Coater, JOEL, Japan) and observed under a scanning electron microscope (JSM-7100, JOEL, Japan). Images were calibrated to determine magnification (Zuckerman et al., 2013). 
Statistic analysis: All experiments were carried out in triplicates. The data were subjected to multifactor Analysis of Variance (ANOVA), followed by the Least Significant Difference (LSD) test to determine the significant difference between samples at $\mathrm{p}<0.05$ level using the software SPSS V.16.

\section{RESULTS AND DISCUSSION}

Evaluation of egg white hydrolysates: The average droplet size, difference between the maximum and minimum diameter of droplets of the dispersed phase and the degree of their dispersion are considered as the significant parameters characterizing a given emulsion (Dajnowiec et al., 2016). The droplet size distribution influences the properties of the emulsion in aspects such as degradation rates, long-term stability, texture and optical appearance (Jurado et al., 2007; Fernandez et al., 2004).

In the current study, oil droplet particle size was used to evaluate the emulsifying properties of hEWs by using different enzymes. Mean diameters of oil droplets $\left(d_{3,2}\right)$ in the emulsions stabilized by different hEWs were shown in Table 2. The largest particle size was found in Peptide $\mathrm{S}$, referring to lower emulsifying property of Peptide S. The average particle sizes of hEW samples (PNY, T, PM) were observed less than that of NEw and Peptide S. It was reported that smaller particle size allowed the protein to coat the fat or water droplets more efficiently as there were more particles available to form a monolayer (Homco-Ryan et al., 2003).

In this study, pork meat slices were soaked in the hEW solutions, thus solubility of hEW was one of important factors to evaluate its possible application in meat slices. Degradation of proteins by a proteolytic enzyme was widely used to increase the solubility and retain the nutritional values of proteins (Adler-Nissen, 1976). According to Table 2, solubility did not differ between NEw and Peptide S, solubility of hEW (PNY, $\mathrm{T}$ and $\mathrm{PM}$ ) decreased compared with NEw. This inconsistence may have occurred due to high temperature $\left(90^{\circ} \mathrm{C}\right)$ used for inactivation of enzymes during the preparation of $\mathrm{hEW}$, which led to the appearance of some insoluble aggregates, while freeze drying didn't not affect the high solubility of NEw. The order of solubility of hEW was as follows: $\mathrm{PNY}>\mathrm{PM}>\mathrm{T}$. Significant WHC difference existed

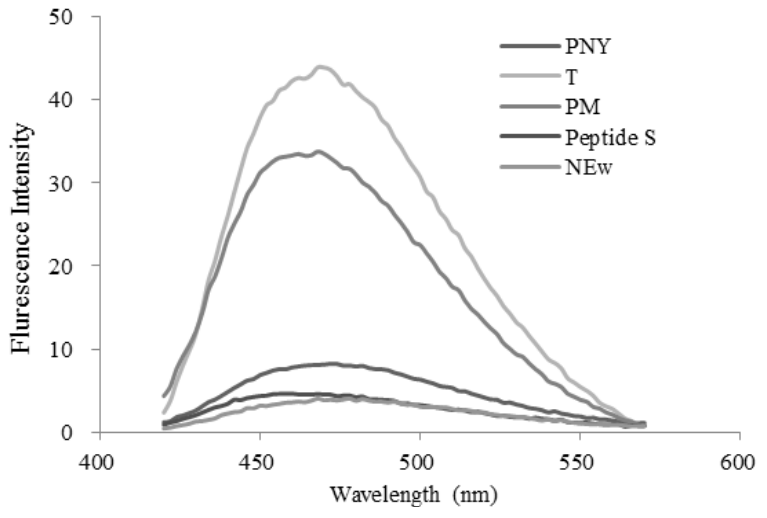

Fig. 1: Fluorescence emission spectra of ANS in the presence of egg white hydrolysates and native egg white. PNY: Egg white hydrolyzed by Protin NY100 ${ }^{\circledR}$; T: Egg white hydrolyzed by Thermoase $\mathrm{PC} 10 \mathrm{~F}^{\mathbb{B}}$; PM: Egg white hydrolyzed by Protease $\mathrm{M}^{\circledR}$; NEw: native egg white; Peptide S: highly hydrolyzed commercial egg white peptides

among hEW (PNY, T and PM), sample $\mathrm{T}$ was able to retain nearly $90 \%$ of the water that it absorbed. WHC of NEw and Peptide $S$ were fairly low, almost 0 , which means that NEw and Peptide S could not retain any water that they absorbed. Regarding OBC, all samples were quite low. Furthermore, $\mathrm{OBC}$ decreased after hydrolysis.

Surface hydrophobicity was reported to have a great significance in elucidating the protein function (Kato and Nakai, 1980). Figure 1 shows the fluorescence intensity of the hEW prepared by various enzymes and NEw solutions, as the wavelength changes. It was observed that the solution prepared by $\mathrm{T}$ showed the highest fluorescence intensity compared to other samples. Except for small peptide S, solutions prepared by $\mathrm{hEW}$ microparticles showed an increase in fluorescence intensity compared to solution prepared by $\mathrm{NEw}$, this result was in accordance with our former study (Wang et al., 2018), partial hydrolysis contributed to an increase of surface hydrophobicity. High surface hydrophobicity indicating a better molecule flexibility and higher expansion degree of proteins, thus resulted in a better adsorption capacity onto oil/water interface (Chang et al., 2016 a; Chang et al., 2016 b).

Cook loss and shrinkage: Data of hEW in meat model system were shown in Table 3. Pork meat slices with a

Table 2: Mean diameter of oil droplets $\left(\mathrm{d}_{3,2}\right)$ in the emulsions stabilized by different egg white hydrolysates, solubility, Water-Holding Capacity (WHC) and Oil-Binding Capacity (OBC) in different egg white hydrolysates and native egg white

\begin{tabular}{llllll}
\hline & PNY & $T$ & PM & Peptide S & NEw \\
\hline $\mathrm{d}_{3,2}$ & $42.5 \pm 0.50^{\mathrm{c}}$ & $27.3 \pm 0.40^{\mathrm{e}}$ & $34.1 \pm 0.80^{\mathrm{d}}$ & $116.8 \pm 1.12^{\mathrm{a}}$ & $106 \pm 0.30^{\mathrm{b}}$ \\
Solubility & $79.64 \pm 0.51^{\mathrm{b}}$ & $61.94 \pm 0.75^{\mathrm{d}}$ & $70.22 \pm 1.06^{\mathrm{c}}$ & $94.84 \pm 1.19^{\mathrm{a}}$ & $95.31 \pm 1.20^{\mathrm{a}}$ \\
WHC & $14.67 \pm 3.21^{\mathrm{c}}$ & $89.28 \pm 8.60^{\mathrm{a}}$ & $77.63 \pm 10.68^{\mathrm{b}}$ & $0.02 \pm 0.02^{\mathrm{d}}$ & $0.01 \pm 0.01^{\mathrm{d}}$ \\
OBC & $4.15 \pm 0.12^{\mathrm{b}}$ & $2.69 \pm 0.27^{\mathrm{c}}$ & $4.51 \pm 0.09^{\mathrm{b}}$ & $5.60 \pm 0.72^{\mathrm{b}}$ & $8.98 \pm 0.61^{\mathrm{a}}$ \\
\hline
\end{tabular}

(Means \pm SD are shown $(n=3)$. In each tested parameter, different superscript letters indicate significant differences between means in the same row $(\mathrm{p}<0.05)$. PNY: Egg white hydrolyzed by Protin NY100 $;$; : Egg white hydrolyzed by Thermoase PC10F ${ }^{\circledR}$; PM: Egg white hydrolyzed by Protease $\mathrm{M}^{\circledR}$; NEw: native egg white; Peptide S: highly hydrolyzed commercial egg white peptides.) 
Adv. J. Food Sci. Technol., 14(6): 186-193, 2018

Table 3: Absorption rate (\%), cooking loss (\%), shrinkage (\%) and water content of meat slices soaked in different egg white hydrolysates

\begin{tabular}{lllll}
\hline & Absorption rate $(\%)$ & Cooking loss $(\%)$ & Shrinkage (\%) & Water content (\%) \\
\hline PNY & $14.88 \pm 2.41^{\mathrm{ab}}$ & $24.43 \pm 0.95^{\mathrm{bc}}$ & $6.90 \pm 1.38^{\mathrm{c}}$ & $68.22 \pm 0.48^{\mathrm{a}}$ \\
T & $19.16 \pm 2.41^{\mathrm{a}}$ & $22.87 \pm 1.74^{\mathrm{c}}$ & $3.24 \pm 0.61^{\mathrm{d}}$ & $68.87 \pm 1.61^{\mathrm{a}}$ \\
PM & $16.33 \pm 1.07^{\mathrm{ab}}$ & $24.37 \pm 1.95^{\mathrm{bc}}$ & $4.67 \pm 1.93^{\mathrm{cd}}$ & $66.40 \pm 0.55^{\mathrm{a}}$ \\
NEw & $11.96 \pm 1.38^{\mathrm{b}}$ & $27.21 \pm 2.29^{\mathrm{b}}$ & $9.07 \pm 0.18^{\mathrm{b}}$ & $67.33 \pm 0.96^{\mathrm{a}}$ \\
Peptide S & $14.92 \pm 3.38^{\mathrm{ab}}$ & $26.75 \pm 3.28^{\mathrm{b}}$ & $6.14 \pm 1.99^{\mathrm{c}}$ & $66.42 \pm 0.76^{\mathrm{a}}$ \\
Control & $1.47 \pm 0.27^{\mathrm{c}}$ & $38.02 \pm 2.02^{\mathrm{a}}$ & $22.74 \pm 1.16^{\mathrm{a}}$ & $62.40 \pm 0.47^{\mathrm{b}}$ \\
\hline
\end{tabular}

(Means \pm SD are shown $(n=3)$. In each tested parameter, different superscript letters indicate significant differences between means in the same column $(\mathrm{p}<0.05)$.
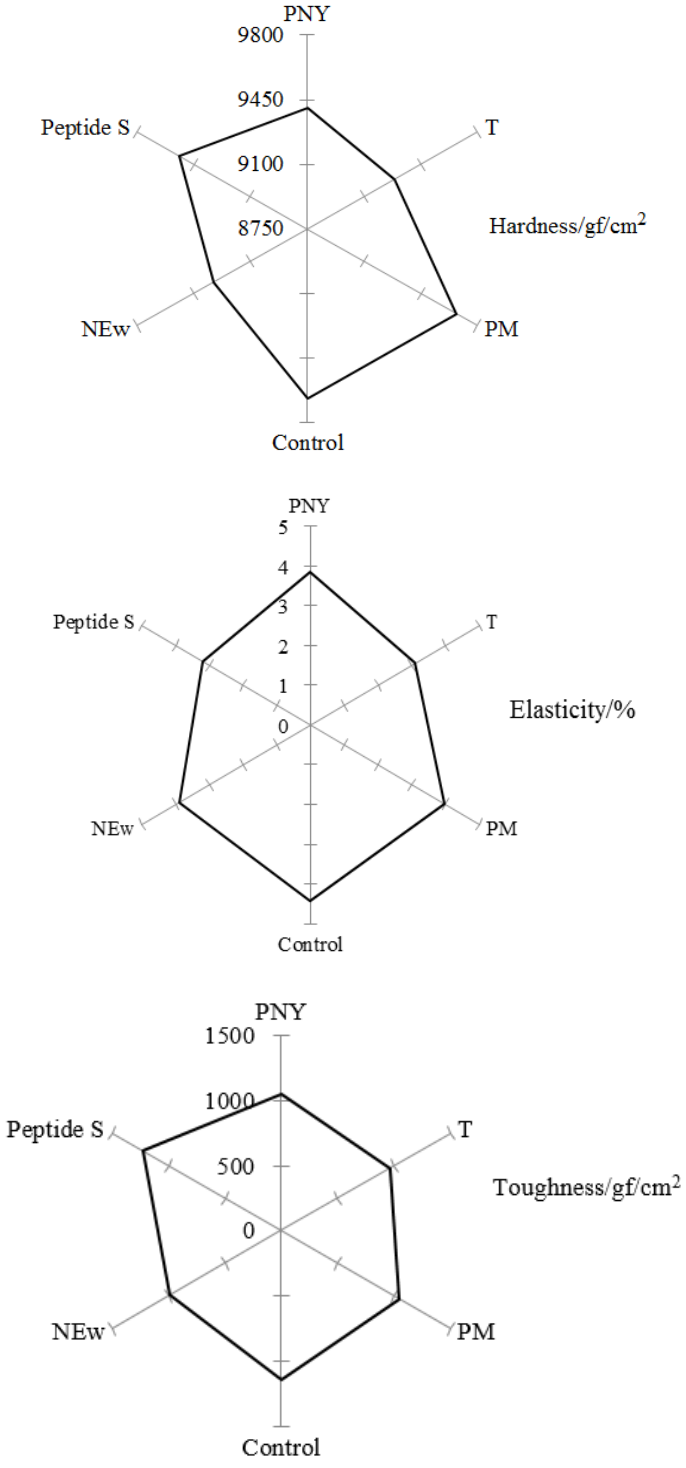

Fig. 2: Texture evaluation of meat slices soaked in different egg white hydrolysates (Fig.1)

thickness of $4 \mathrm{~mm}$ and an uniform size were soaked in hEW or NEw solutions. The weight change percentage of meat slice soaked in corresponded dispersion was expressed as absorption rate (\%). It is obvious to observe that absorption rates of all hEW as well as NEw samples were significantly higher than that of the control (meat slice soaked in only water). The existence of proteins exposed at the interface contributed to the penetration of liquid from surroundings into the inside of meat. Peptide $\mathrm{S}$ showed the same absorption rate with three hEW samples (PNY, T and PM), which suggested that absorption rate is not associated with the particle size of proteins, $\mathrm{pH}$ may be an additional consideration.

Changes in meat proteins and the majority of water is held in myofibrils, water content within the meat myofibrils in the narrow channels between the filaments changes as meat shrinks within the tissue matrix, resulting in cook loss with heating.

(Huff-Lonergan and Lonergan, 2005). Cooking loss was calculated as the percent weight difference between fresh and cooked samples with respect to the weight fresh meat samples (Chiavaro et al., 2009). Both NMR and cooking studies have shown that the water loss during cooking of minced or hamburger muscle is similar to that of intact meat muscle (Tornberg, 2005; Bertram et al., 2004; Bertola et al., 2010). Meat tissue is known to shrink laterally and longitudinally. Meat cook shrinkage is the difference between the raw and cooked areas of the meat sample, expressed as a percentage of the raw area (Barbera and Tassone, 2006). In this study, meat shrinkage was measured by archiving the image of raw and cooked meat samples. Results showed that when pork meat slice was immersed in only water (control), after cook, about $38.0 \%$ of weight was lost (cooking loss) and the shrinkage rate was about $22.7 \%$. Similarly, Tornberg (2005) also reported a considerable shrinkage of meat $7-19 \%$ on area basis. Furthermore, it is obvious to find that cooking loss as well as shrinkage rate decreased when raw meat was immersed in the solution which containing hEW (PNY, T, PM and Peptide S) and NEw. The meat treated by sample $\mathrm{T}$ which possessed an excellent WHC resulted in the least shrinkage (3.24\%).

The ability of an added substance to increase meat batter $\mathrm{pH}$ can allow muscle proteins to be much more successful in increasing a stable emulsion (HomcoRyan et al., 2003). Water content of cooked meat is related to juiciness of meat, which is also one of important sensory factors. Results showed that there were no significant differences among meat treated by hEW (PNY, T, PM and Peptide S) and NEw, a relatively lower water content was observed in the cooked meat treated by only water (control). 

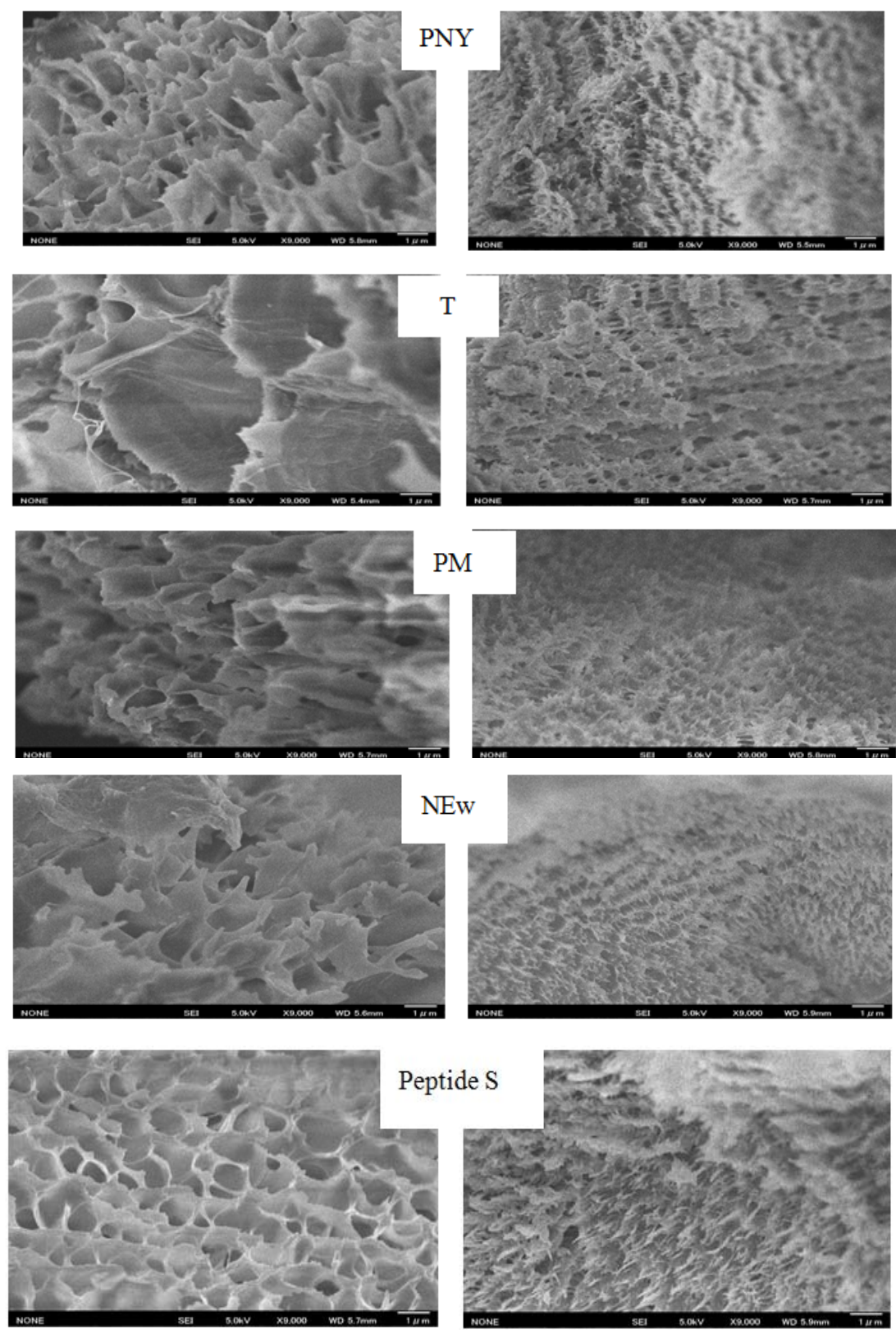

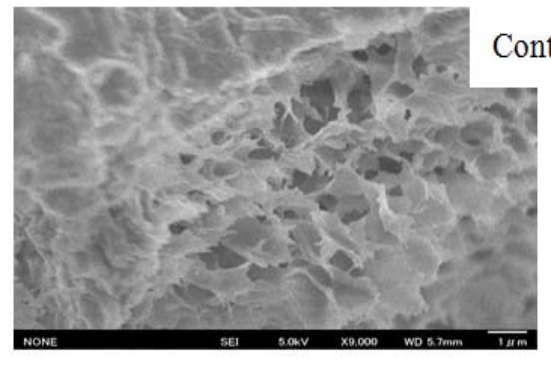

Refore conk

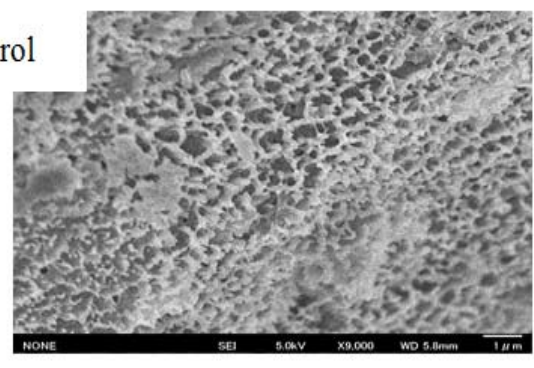

After conk

Fig. 3: Scanning electron microscope of meat slices (before and after cook) soaked in different egg white hydrolysates

Texture: Consumer satisfaction has been influenced by meat textural properties (Silva et al., 2015). Changes on texture caused by heating could be affected by changes in the soluble proteins, myofibrillar proteins and connective tissue of meat. Heating produced a softening of connective tissue and a toughening of meat fibers 
(Bouton and Harris, 2010). In this study, three textural parameters (hardness, elasticity and toughness) of cooked meat were evaluated. As shown in Fig. 2, although relative higher water content was observed in meat immersed in Peptide S and PM solution compared to the control, there was no significant difference observed among the hardness of these three kinds of meat. The greatest elasticity and toughness of cooked meat was observed in the meat soaked in water (control). As myoglobin is water-soluble in meat, when meat was soaked in only water, the loss of myoglobin resulted in the largest hardness, elasticity and toughness. While in the meat treated in the solution which containing hEW (PNY, T, PM and Peptide S) and NEw, proteins with small size were penetrated into the connected tissue matrix of meat muscle tissues and these proteins showed WHC, OBC as well as emulsifying capacities, acted as a binder of water and fat component in the meat, affected textures in the final cooked meat.

Micro structure: In this study, a Scanning Electron Microscopy (SEM) technique was utilized to investigate the difference among the microstructure of intramuscular connective tissue in pork meat muscles. As shown in Fig. 3, honeycomb structures of the endomysium were clearly observed within muscle fiber bundles in all the meat. Relative larger holes and a grainy appearance of endomysium sheaths were distinctive in the meat treated by $\mathrm{T}$, while collagen fibril disruption and the rainy appearance of endomysium sheaths were not prevalent in the sample treated by Peptide S. Despite of difference observed among these raw pork meat slices, after cooking, honeycomb structures in all the meat became smaller than before cooking, the shrinkage of connective tissue network and muscle fiber occurred.

\section{CONCLUSION}

In this study, physical characteristic including solubility, water holding capacity and oil binding capacity of different hEWs were evaluated. Furthermore, shrinkage and cooking loss of pork meat slices soaked in different hEWs were compared. Results showed that, cooking loss and shrinkage rate decreased when pork slices were soaked in the solution containing hEWs (PNY, T, PM and Peptide S) and NEw, compared with slice soaked in only water. The meat treated by sample $\mathrm{T}$ which possessed an excellent WHC resulted in the least shrinkage rate $(3.24 \%)$ compared with the control (shrinkage rate of $22.7 \%$ ). Treated by hEWs and NEw contributed to the decrease of elasticity and toughness of cooked meat. Therefore, it is concluded that treatment of pork meat slices in egg white hydrolysates is beneficial for decreasing the shrinkage and weight loss during heating.

\section{ACKNOWLEDGMENT}

The author would like to thank Professor Yasuki Matsumura of Kyoto University for his instructions in the determination of particle size distributions of egg white hydrolysates. The authors also would like to thank Dr. Yosie Ueno of Kyoto Prefectural Technology Center for Small and Medium Enterprises for his help in the observation of microstructure of meat by a scanning electron microscopy.

\section{REFERENCES}

Adler-Nissen, J., 1976. Enzymatic hydrolysis of proteins for increased solubility. J. Agric. Food Chem., 24(6): 1090-1093.

Barbera, S. and S. Tassone, 2006. Meat cooking shrinkage: Measurement of a new meat quality parameter. Meat Sci., 73(3): 467-474.

Bertram, H.C., M. Kristensen and H.J. Andersen, 2004. Functionality of myofibrillar proteins as affected by ph, ionic strength and heat treatment- a lowfield NMR study. Meat Sci., 68(2): 249-256.

Bertola, N.C., A.E. Bevilacqua and N.E. Zaritzky, 2010. Heat treatment effect on texture changes and thermal denaturation of proteins in beef muscle. J. Food Process. Preserv., 18(1): 31-46.

Bouton, P.E. and P.V. Harris, 2010. The effects of cooking temperature and time on some mechanical properties of meat. J. Food Sci., 37(1): 140-144.

Chang, C., F. Niu, L. Gu, X. Li, H. Yang and et al., 2016. Formation of fibrous or granular egg white protein microparticles and properties of the integrated emulsions. Food Hydrocolloids, 61: 477486.

Chiavaro, E., M. Rinaldi, E. Vittadini and D. Barbanti, 2009. Cooking of pork longissimus dorsi at different temperature and relative humidity values: Effects on selected physico-chemical properties. J. Food Eng., 93(2): 158-165.

D'Appolonia, B.L., 1977. Rheological and baking studies of legume-wheat flour blends. Cereal Chem., 54(1): 53-63.

Dajnowiec, F., P. Banaszczyk, A. Kubiak, M. Biegaj and L. Zander, 2016. The study on oil droplet size distribution in $\mathrm{O} / \mathrm{W}$ emulsions prepared by the use of the asymmetric membrane. Pol. J. Natur. Sc., 31(4): 665-680.

Dominguez, R., M. Goméz, S. Fonseca and J.M. Lorenzo, 2014. Effect of different cooking methods on lipid oxidation and formation of volatile compounds in foal meat. Meat Sci., 97(2): 223230.

Fernandez, P., V. André, J. Rieger and A. Kühnle, 2004. Nano-emulsion formation by emulsion phase inversion. Colloids Surf Physicochem. Eng. Asp., 251(1-3): 53-58. 
Glorieux, S., O. Goemaere, L. Steen and I. Fraeye, 2017. Phosphate reduction in emulsified meat products: Impact of phosphate type and dosage on quality characteristics. Food Technol. Biotechnol., 55(3): 390-397.

Homco-Ryan, C.L., K.J. Ryan and M.S. Brewer, 2003. Comparison of functional characteristics of modified corn gluten meal in vitro and in an emulsified meat model system. J. Food Sci., 68(9): 2638-2643.

Huff-Lonergan E. and S.M. Lonergan, 2005. Mechanisms of water-holding capacity of meat: The role of postmortem biochemical and structural changes. Meat Sci., 71(1): 194-204.

Jurado, E., V. Bravo, F. Camacho, J.M. Vicaria and A. Fernández-Arteaga, 2007. Estimation of the distribution of droplet size, interfacial area and volume in emulsions. Colloids Surf. Physicochem. Eng. Asp., 295(1-3): 91-98.

Kato, A. and S. Nakai, 1980. Hydrophobicity determined by a fluorescence probe method and its correlation with surface properties of proteins. Biochim. Biophys. Acta, 624(1): 13-20.

Keeton, J.T., 2001. Formed and emulsion products, In: Sams. A.R., (Ed.): Poultry Meat Processing, CRC Press, Boca Ranton, Florida, USA, pp: 195-226.

Long, N.H.B.S., R. Gál and F. Buňka, 2006. Use of phosphates in meat products. Afr. J. Biotechnol., 2011(10): 19874-19882.

Markwell, M.A.K., S.M. Haas, L.L. Bieber and N.E. Tolbert, 1978. A modification of the Lowry procedure to simplify protein determination in membrane and lipoprotein samples. Anal. Biochem., 87(1): 206-210.

Marshall, N., L. Wood and M.B. Patton, 1960. Cooking choice grade top beef roasts. J. Am. Diet. Assoc., 36: 341-345.

Mittal, G.S. and W.R. Usborne, 1985. Meat emulsion extenders. Food Technol., 39(4): 121-130.

Omana, D.A., Z. Pietrasik and M. Betti, 2012 Evaluation of poultry protein isolate as a food ingredient: Physicochemical characteristics of lowfat turkey bologna. Poult. Sci., 91(12): 3223-3229.
Pathare, P.B. and A.P. Roskilly, 2016. Quality and energy evaluation in meat cooking. Food Eng. Rev., 8: 435-447.

Penfield, M.P. and B.H. Meyer, 1975. Changes in tenderness and collagen of beef semltendlnosus muscle heated at two rates. J. Food Sci., 40: 150154.

Pigott, R.S., P.B. Kenney, S. Slider and M.K. Head, 2010. Formulation protocol and dicationic salts affect protein functionality of model system beef batters. J. Food Sci., 65(7): 1151-1154.

Ritz, E., K. Hahn, M. Ketteler, M.K. Kuhlmann and J. Mann, 2012. Phosphate additives in food--a health risk. Dtsch. Arztebl. Int., 109(4): 49-55.

Seguchi, M., 2010. Oil-binding ability of gelatinized prime starch granules from chlorinated wheat flour. Starch-Stärke, 37(4): 116-118.

Silva, D.R.G., R.A.T. Filho, H.P. Cazedey, P.R. Fontes, A.L.S. Ramos and et al., 2015. Comparison of Warner-Bratzler shear force values between round and square cross-section cores from cooked beef and pork longissimus, muscle. Meat Sci., 103: 1-6.

Tornberg, E., 2005. Effects of heat on meat proteinsimplications on structure and quality of meat products. Meat Sci., 70(3): 493-508.

Yarmand, M.S., P. Nikmaram, Z.E. Djomeh and A. Homayouni, 2013. Microstructural and mechanical properties of camel longissimus dorsi muscle during roasting, braising and microwave heating. Meat Sci., 95(2): 419-424.

Wang, Y., Y. Horimoto, F. Nau. and H. Hatta, 2018. Improving emulsifying properties of egg white protein by partial hydrolysis combined with heat treatment. Adv. J. Food Sci. Technol., 14(2): 5055.

Zuckerman, H., B.C. Bowker, J.S. Eastridge and M.B. Solomon, 2013. Microstructure alterations in beef intramuscular connective tissue caused by hydrodynamic pressure processing. Meat Sci., 95(3): 603-607. 